March 1988

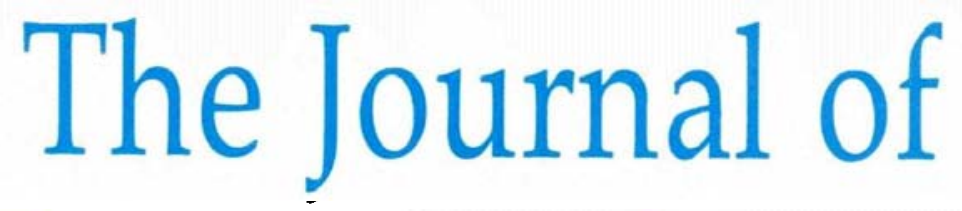

Laryngology

and Otology
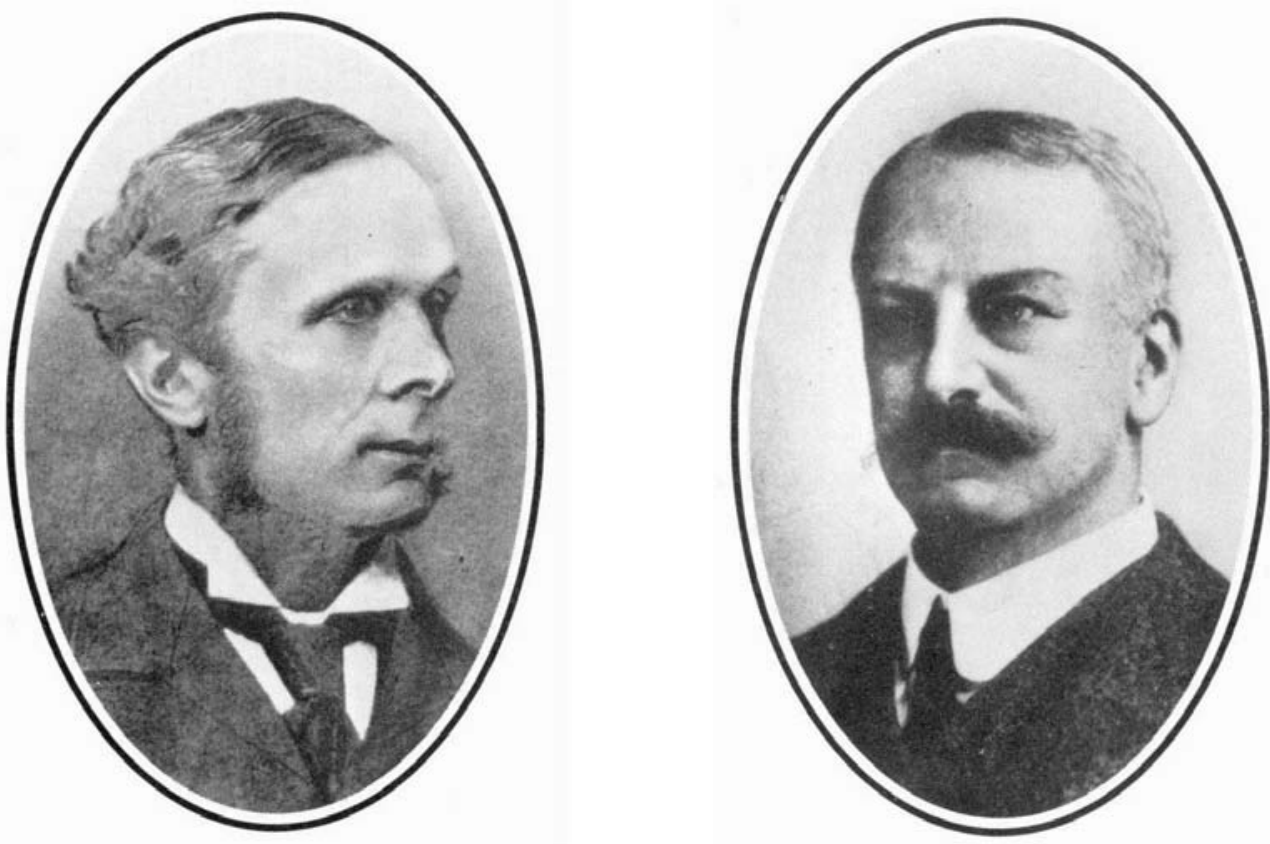

Founded in 1887 by Morell Mackenzie \& Norris Wolfenden

Vol 102

No 3
Edited by JOHN B. BOOTH

Assistant Editors DAVID WRIGHT, NEIL WEIR, PATRICK BEASLEY \& CAROL WENGRAF Adviser in Pathology IMRICH FRIEDMANN 


\section{The Journal of Laryngology and Otology}

(Founded in 1887 by MORELL MACKENZIE and NORRIS WOLFENDEN)

EDITOR

JOHN B. BOOTH

ASSISTANT EDITORS

DAVID WRIGHT, NEIL WEIR, PATRICK BEASLEY AND CAROL WENGRAF

INSTRUCTIONS FOR AUTHORS

1. Original articles which have not been published elsewhere are invited and should be sent to the Editor. They are considered for publication on the understanding that they are contributed to this Journa/ solely. Reproduction elsewhere, in whole or in part, is not permitted without the previous written consent of the Author and Editor and the customary acknowledgement must be made. Normally an original main article should not exceed 7500 words.

Longer articles or theses will be considered for publication as Supplements, at the expense of the authors or their employing authorities.

2. Manuscripts should be typewritten in duplicate on one side only of the paper (A4 $297 \times 210 \mathrm{~mm}$ ) and double spaced, with wide margins.

Begin each component on a new page in the following sequence: title page, abstract, text, acknowledgements, references, tables and legends.

(a) Abstract-This should contain not more than 150 words and include a statement of the problem, the method of study, results and conclusions; a 'summary' section should not be included in the main manuscript.

(b) Text-Suggested outline-(1) introduction, (2) materials and methods, (3) results, (4) discussion, (5) conclusion.

(c) Tables are adjuncts to the text and should not repeat material already presented.

(d) Illustrations should be of sufficient size that when reduced for publication, the features are still clearly visible, indicators such as arrows must remain clearly identifiable and that labelling is still legible. Reproductions of $X$-rays, photomicrographs, CT scans, etc. should ideally be trimmed before submission; alternatively an overlay or other copy should also be provided giving an indication of what reduction of the margins would be acceptable to the author.

Written permission from both senior author and publisher must be provided to the Journal in order to republish materials with copyright elsewhere.

(e) Measurements must be in metric units, with Système Internationale (SI) equivalents given in parentheses.

(f) References-For Journa/ articles, The Harvard system of recording references should be used, e.g. Green, C. and Brown,

D. (1951). The tonsil problem. Journal of Laryngology and Otology 65: 33-38. A paper written by more than two authors should be abbreviated in the text, e.g. Green et al. 1951, but al/ the authors should be given in the list of references. The titles of all Journals should be given without abbreviation. References should be fisted in alphabetical order; use of the Vancouver system will not be accepted.

For single-author books, the following style should be used: Green, C. (1951). The tonsil problem, 2nd edn., vol. 1, Headley Brothers Ltd., Ashford, Kent, 98 pp.

For papers in multi-author books with one or more editors, the reference should be recorded as follows: Brown, D. (1951). In Diseases of the Ear, Nose and Throat (White, A. and Black, B., eds.), pp. 33-38, Headley Brothers Ltd., Ashford, Kent.

It is most important that authors should verify personally the accuracy of every reference before submitting a paper for publication. The names of authors cited in the References should be given in alphabetical order.

(g) Meetings - If the manuscript was presented at a meeting, the place where it was held, and the date on which it was read must be included and should appear at the foot of the title page.

(h) Financial disclosures-In the submission letter to the Editor, the authors must list all affiliations with or financia involvement in, organizations or entities with a direct financial interest in the subject matter or material of the research discussed in the manuscript.

3. Page proofs are sent to authors for corrections, which should be kept to a minimum; they must be clearly marked, and no extra matter added. Proofs should be returned within 5 days. Coloured illustrations will be charged to authors, unless a special grant is authorized by the Editor.

4. Orders for reprints must be sent when returning page proofs, and for this purpose special forms are supplied.

5. Editorial communications may be addressed to The Editor, Journal of Laryngology and Otology, c/o Headley Brothers Ltd., The Invicta Press, Ashford, Kent TN24 8HH.

6. The annual subscription is $\mathbf{f 5 0}$ (fifty pounds sterling) post free; U.S.A. $\$ 123$ post free, and payable in advance.

7. Single copies of current or back numbers (when available) will be on sale at $\mathrm{f} 10$ each (including postage)

8. All subscriptions, advertising and business communications should be sent to the publishers, or subscription agents.

\section{HEADLEY BROTHERS LTD, THE INVICTA PRESS, ASHFORD, KENT.}

(C) Journal of Laryngology and Otology Ltd., 1988

ISSN 0022-2151

Second class postage paid Rahway, N.J.

Postmaster: Send address corrections to The Journal of Laryngology and Otology, c/o Mercury

Airfreight International Ltd. Inc., 10B Englehard Avenue, Avenel, N.J. 07001 


\section{Introducing... Kamplex AC 30}

A two channel, microprocessor-controlled Clinical Audiometer at a cost-effective price - ideal for routine or advanced testing.

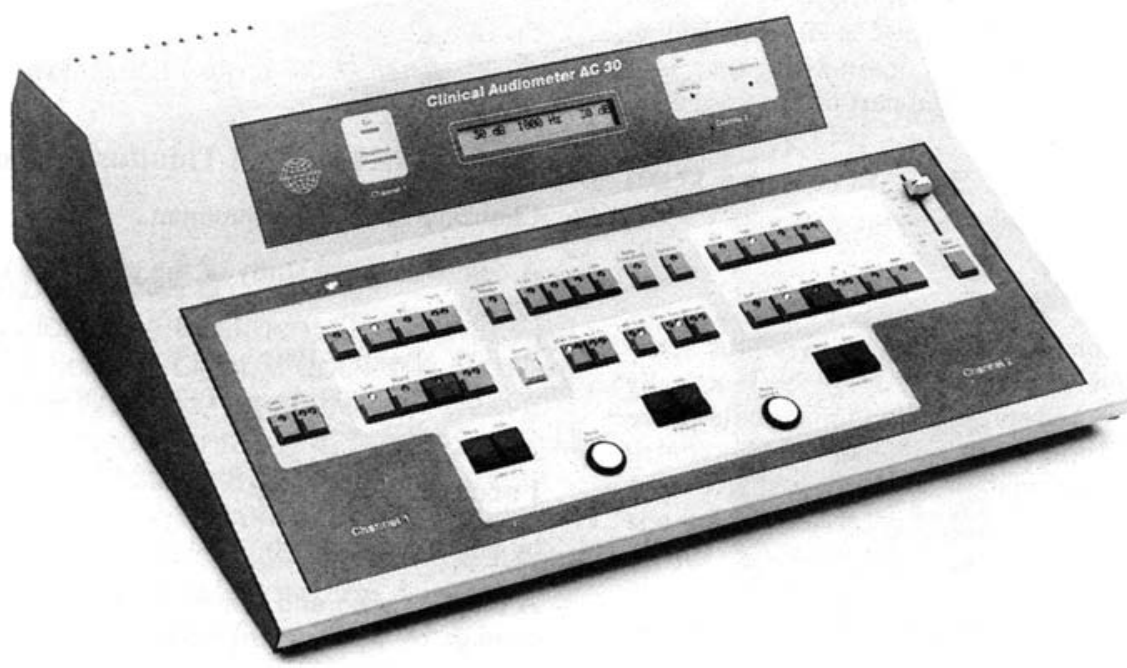

- Performs full range of diagnostic tests

- Two channel flexibility

- Monitor and Printer connections

- Unique Kamplex clickless attenuator circuitry

- Automatic threshold test facility

- RS 232C two-way interface as standard

- Complete two-way communications

- Microprocessor design

- Modern ergonomic styling with convenient liquid crystal display panel

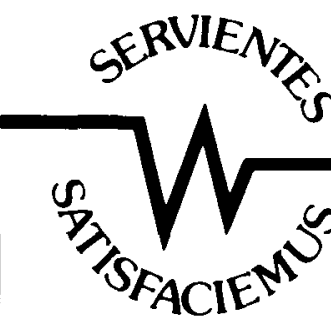

P.C.WERTH LTD

Audiology House, 45 Nightingale Lane, London, SW12 8SP

Telephone: 01-675 5151. Telex: 8955485. Fax: 01-675 7577 


\section{Laryngology \& Otology Publications}

\section{Available from the Publishers and from Agents throughout the world. Prices include postage and packing.}

Supplements still available separately.

\section{Traité de L'Organe de L'Oüe}

by Nehemiah Asherson

This Bibliography of one of the earliest accurate descriptions of the organ of hearing, which first appeared in 1683, represents the culmination of a lifetime of historical research. It includes a biographical section on Du Verney, the author of the 'Traité'.

Pp 110 ISBN 0718604474

Retail $£ 7.00$ Agents $£ 6.12$ (US\$14.00 Agents $\$ 12.25$ )

\section{The ENT Surgeon looks at the Orbit}

by D. F. N. Harrison

This supplement records in some detail Professor Harrison's 'personal experience over a period of 20 years dealing with a wide variety of clinical conditions in which entry into the orbit was a desirable or essential part of treatment'.

Pp 42 Printed 1980

Retail $£ 4.00$ Agents $£ 3.50$ (US\$8.00 Agents $\$ 7.00$ )

\section{Tinnitus}

\section{Chairman: Abraham Shulman}

The Proceedings of The First International Tinnitus Seminar, which was held in New York in June 1979. Practically all the original papers are reproduced in full, and there are edited versions of all the Panel Discussions. The contributions, from an international group of experts, give comprehensive coverage to a subject of great current interest and importance.

Pp 216 Printed 1981

Retail $£ 10.00$ Agents $£ 8.75$ (US\$20.00 Agents $\$ 17.50$ )

20 Years Experience with homografts in ear surgery

by Christian Betow

The author, a professor of Otolaryngology in West Berlin, gives a full account of his pioneering development of homograft materials in reconstructive surgery of the middle ear.

Pp 28 Printed 1982

Retail $£ 4.00$ Agents $£ 3.50$ (US\$8.00 Agents $\$ 7.00$ )

\section{Laryngology Applied to Singers and Actors}

by Norman A. Punt

This fascinating monograph fills an obvious void in laryngological literature. The author, eminent in the field of vocal problems in theatre and opera house, writes with understanding, knowledge and concern. When mixed with valuable advice and useful prescriptions, this monograph will serve to guide all who find themselves called upon to help these most sensitive individuals.

Pp 24 Printed 1983

Retail $£ 4.00$ Agents $£ 3.50$ (US\$8.00 Agents $\$ 7.00$ )

\section{Experimental and Clinical Studies in Otitis Media with Effusion}

by Jamsheed A. Khan

An experimental and clinical study on the effects of Carbocisteine on fluid in the middle ear.

Pp 28 Printed 1983

Retail $£ 4.00$ Agents $£ 3.50$ (US\$8.00 Agents $\$ 7.00$ )

Proceedings of the Sixth British Academic Conference in Otolaryngology

Edited by John Ballantyne and John Booth

Pp 134 Printed 1983

Retail $£ 5.00$ Agents $£ 4.50$ (US\$10.00 Agents \$7.50)

\section{Second International Tinnitus Seminar}

Chairman: Abraham Shulman

A comprehensive study of the problems and treatment of tinnitus.

Pp 323 Printed 1984

Retail $£ 20.00$ Agents $£ 17.50$ (US\$40.00 Agents $\$ 35.00$ )

\section{Forensic Audiology}

by Chuang Wei Ping

A clear concise and practical guide to industrial hearing damage by a barrister/physician. This is an unusual and highly specialised aide memoire for the personal injuries practitioner, well illustrated with recent case law. A commendable enterprise by the author.

Pp 57 Printed 1986

Retail $£ 7.00$ Agents $£ 6.12$ (US\$14.00 Agents $\$ 12.25$ )

\section{The Acute Orbit}

Preseptal (Periorbital) cellulitis subperiosteal abscess and orbital cellulitis due to sinusitis.

by J. R. Moloney, N. J. Badham and A. McRae

Pp 18 Printed 1987

Retail $£ 7.00$ Agents $£ 6.12$ (US\$14.00 Agents $\$ 12.25$ )

Nasal Mast Cells: A Preliminary Report on their Ultrastructure

by A. B. Drake-Lee, FRCS

Pp 17 Printed 1987

Retail $£ 10.00$ Agents $£ 8.75$ (US\$20.00 Agents $\$ 17.50$ ) 


\section{THE ALTOMED E.N.T.TREATMENT CENTRE RANGE}

\section{STANDARD MODELS}

EDC 200 double size treatment Centre with Suction, Examination Light, 4 Lockable Drawers, Stainless Steel Worktop, mounted on 4 heavy Duty Castors. Dimensions: W. $42^{\prime \prime} \times$ D. $21^{\prime \prime} \times \mathrm{H}$. $32^{\prime \prime}(1070 \mathrm{~mm} \times 553 \mathrm{~m} \times 815 \mathrm{~mm})$.

EDC 1000 single size Treatment Centre with Suction and Examination Light, Stainless Steel Worktop, two Drawers. Mounted on 4 heavy Duty Castors. Dimensions: W. $21^{\prime \prime} \times$ D. $21^{\prime \prime} \times H$. $32^{\prime \prime}(553 \mathrm{~mm} \times 553 \mathrm{~m} \times 815 \mathrm{~mm})$.

\section{OPTIONAL EXTRAS}

Cupboard \& Shelf Module for Double Size Unit Cupboard \& Shelf Module for Single Size Unit $X$-Ray Viewer

Welch-Allyn Otoscope

Cautery Handle with 3 burners

Light Source for fibre Optic Instruments CLAR Headlight

Mirror Warmer

Basin Holder with Stainless Steel Basin Standard finish 'Cream'. Natural Wood Finish available to special order.

Full Consulting Room Outfitting and Special Design Service available upon request.

ALTOMED LTD, PARK HOUSE, PARK ROAD, GATESHEAD, TYME \& WEAR, ENGLAND.

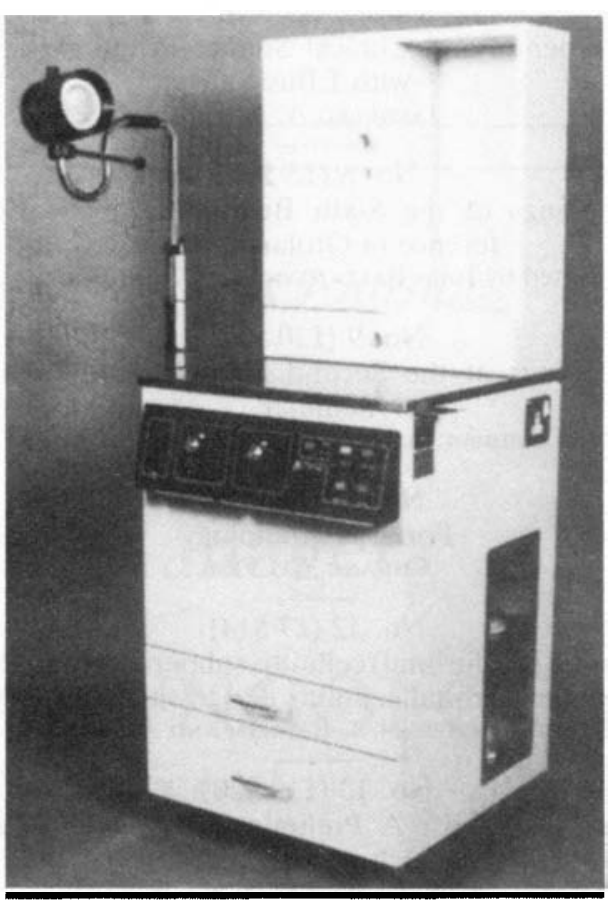

Single cabinet with module.

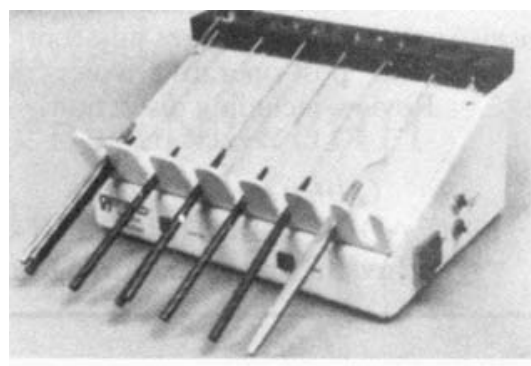

Mirror warmer 


\section{The Journal of Laryngology and Otology SUPPLEMENTS}

No. $2(£ 7 \$ 14)$

Traité de l'Organe de L'Ouïe

Nehemia Asherson, M.A., M.B.B.S., F.R.C.S.

No.3 (£4\$8)

The ENT Surgeon Looks at the Orbit

D. F. N. Harrison, M.D., M. S., F.R.C.S., (Hon) F.R.A.C.S.

No. $4(£ 10 \$ 20)$

Tinnitus

Proceedings of the First International Tinnitus Seminar

Chairman: Abraham Schulman, M.D.

No. $5(£ 4 \$ 8)$

20 Years experience with homografts in ear surgery Christian Betow

No. $6(£ 4 \$ 8)$

Laryngology applied to singers and actors

Norman A. Punt, F.R.C.S., E.D., M.R.C.S., L.R.C.P. D.L.O.

No. $7(£ 4 \$ 8)$

Experimental and Clinical Studies in Otitis Media with Effusion

JAMSHEED A. KHAN

No. $8(£ 5 \$ 10)$

Proceedings of the Sixth British Academic Conference in Otolaryngology

Edited by John BaLLANTYNE and JoHN Booth

$$
\text { No. } \overline{9(£ 20} \$ 25)
$$

Proceedings of the Second International Tinnitus Seminar

Chairman: Abraham Schulmann, M.D.

No. $11(£ 7 \$ 14)$

Forensic Audiology

Chuang Wei Ping

No. $12(£ 7 \$ 14)$

Preseptal (Periorbital) cellulitis subperiasteal abscess and orbital cellulitis due to sinusitis

J. R. Maloney, N. J. Badham and A. McRae

$$
\text { No. } 13(£ 10 \$ 20)
$$

Nasal Mast Cells: A Preliminary Report on their Ultrastructure

A. B. Drake-LeE, F.R.C.S.

No. $\overline{14(£ 10} \$ 20)$

Surgical Anatomy of Structures adjacent to the thyroid apex and post-operative voice change (A Review including dissection).

K. L. YeRzingatSIAN

Obtainable from

HEADLEY BROTHERS LTD

The Invicta Press, Ashford, Kent

\section{The Joupnal of Otolapyncology}

\author{
...the official "voice" of
}

\section{The Canadian Society of Otolaryngology Head and Neck Surgery}

is published in February, April, June, August, October and December

Established in 1972. The Journal of Otolaryngology publishes original papers dealing with clinical and research aspects of otolaryngology in its broadest sense, including:

\section{AUDIOLOGY \\ HEAD AND NECK SURGERY \\ BRONCHO-OESOPHAGOLOGY \\ MAXILLOFACIAL SURGERY \\ FACIAL PLASTIC AND \\ RECONSTRUCTIVE SURGERY \\ COMMUNICATIVE DISORDERS}

The Journal of Otolaryngology, with thirteen corresponding editors contributing from around the world and half of its circulation outside Canada, is a truly international publication.

The Editor, Derek Birt, M.B., of Toronto, hopes that this international "flavour" will serve as a significant factor in your decision to become a new subscriber to The Journal of Otolaryngology.

Subscription Rates: $\$ 75.00$ U.S. per year Back Issues available at $\$ 15.00$ each plus postage

TO: Circulation Manager, The Journal of Otolaryngology

P.O. Box 280. Station A

Islington, Ontario, Canada M9A 4X2

I enclose a cheque for $\$$

to cover subscription(s) to

The Journal of Otolaryngology.

NAME:

ADDRESS:

(Please print or type) 


\title{
THE LARYNGOSCOPE
}

\author{
A Monthly Journal \\ devoted to the disease of \\ EAR, NOSE AND THROAT \\ Official organ for the American Laryngological \\ Rhinological and Otological Society
}

Price $\$ 80.00$ per year Foreign $\$ 100.00$ per year

ESTABLISHED 1896

Gershon J. SPECTOR EDITOR

9216 CLAYTON ROAD, SUITE 18, ST. LOUIS, MISSOURI 63124-1561

For Advertisement Rates and Space in this Journal

$$
\text { apply to }
$$

\section{The Advertisement Manager}

\section{THE JOURNAL OF LARYNGOLOGY AND OTOLOGY}

\author{
Headley Brothers Limited \\ The Invicta Press - Ashford - Kent TN24 8HH \\ Tel: (0233) 23131
}



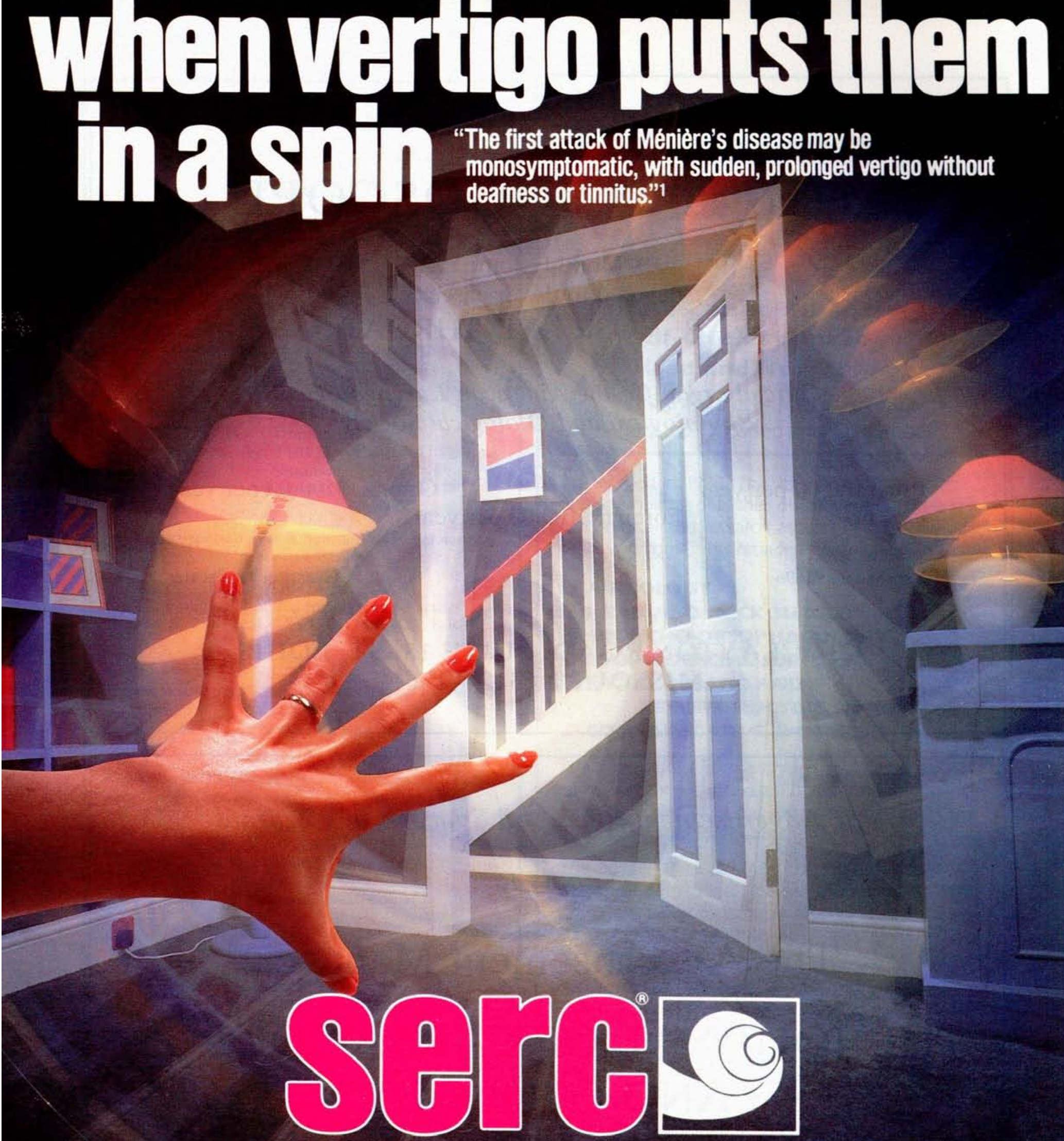

\section{betahistine}

Presentation

White tablets containing $8 \mathrm{mg}$ betahistine dihydrochloride. Available in packs of 120 tablets. Basic NHS price £12.88.

\section{Indications}

Vertigo, tinnitus and hearing loss associated with

Mènière's syndrome.

Dosage and Administration

Adults: Initially two tablets three times daily, taken preferably with meals.

\section{tachlestibe symptoms by treating the cause}

Maintenance dose: 3-6 tablets daily.

Children: No dosage recommendations are made for children.

Contra-indications, Warnings, etc.

Contra-indications: Phaeochromocytoma.

Precautions: Clinical intolerance to Serc in bronchial asthma patients has not been shown, but caution should be exercised when administering this histamine analogue to bronchial asthma patients. Interaction between Serc and antihistamines is theoretically possible, but no reports have been received. The usual precautions should be observed when administering Serc to patients in pregnancy.

Side effects: There have been a small number of reports of gastric upset.

Product Licence Number

0512/0076

\section{Reference:}

1. Venna,N., Geriatric Med. 1986. September, 17-22

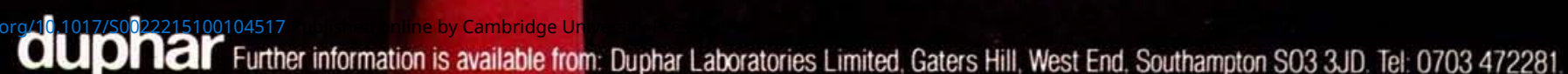

